\title{
ポリマーセメント系塗膜防水層の構造観察とシミュレーション OBSERVATION OF STRUCTURE OF POLYMER CEMENT WATERPROOFING MEMBRANE AND SIMULATION
}

\author{
塚越雅 幸*, 鴻上嘉延**, 田中享二*** \\ Masayuki TSUKAGOSHI, Yoshinobu KOKAMI and Kyoji TANAKA
}

\begin{abstract}
Polymer-cement waterproofing membrane is formed through hydration of cement and solidification of polymers, due to simultaneous water consumption by hydration to cement and water evaporation. Therefore, structures of membranes differ by mixing ratio of cement, polymer and particularly water content. In the study, polymer cement sheets were made by various ratios of the three components, and their structures were investigated through EPMA observation. Furthermore, a simulation model adopted water reduction by hydration and evaporation was developed. The simulated results were compared with observed ones and showed in approximately good accordance with the observed images. Finally structures of the polymer cement waterproofing membranes were discussed on the basis of the two results.
\end{abstract}

Keywords: Polymer cement, Waterproofing Membrane, Microstructure, EPMA, Simulation model ポリマーセメント, 防水層, 微細構造, EPMA, シミュレーション

\section{1.はじめに}

ポリマーセメント系塗膜は、防水層としての使用を目的に、適度 な強度と変形性をもつように作られたセメントとポリマーの複合 材料である。この防水層には、セメント系の粉体が用いられている ため、湿潤な下地面への施工が可能であるほか、もう一つの構成材 料であるポリマーエマルションが水系であるため、施工時の環境へ の負荷も少なく、建築物の地下部分や水槽、ピット等を中心に、様々 な部位に広く使用される。1)

この材料の防水層形成の特徵は、ポリマーエマルション中の水分 がセメントの水和に利用されるためと、表面から乾燥が進むことの 同時作用により内部の水分が減少し、最終的にはポリマー同士が融 着し造膜するという過程にある。そしてポリマーセメント防水層形 成後の物性は、ポリマーとセメント硬化体がどのような構造をとる かに依存する。従ってポリマーセメント系塗膜防水層の物性の理解 には、防水層がどのように形成され、どの様な構造になるかを明ら かにする必要がある。

本研究では、これらの背景のもと、エチレン酢酸ビニル系共重体 エマルジョンを主要材料としたポリマーセメント系防水材を例と して、ポリマーとセメント硬化体がどのような組織構成となるのか を、いくつかの機器による防水層形成後のポリマーセメントの構造
観察と、シミュレーションにより明らかにする事を目的とする。

\section{2. 既往の研究}

ポリマーの造膜過程 ${ }^{2,3)}$ と、セメントの水和進行過程 ${ }^{4,5)}$ について は、それぞれの分野で多くの研究がなされている。また、建築分野 におけるポリマーとセメントの複合材料は, ポリマーセメントモル タル，ポリマーセメントコンクリートといった形で、仕上げ材料や 補修材料に広範囲で利用されており、研究の蓄積も多い $6,7,8,9,10)$ 。 しかしそれらは、ポリマー混入量がそれほど多くない領域を対象と しているのに対して、防水層用のポリマーセメントではポリマー混 入率が最低でも $25 \%$ 、多い場合は $100 \%$ を超えることもあることか ら、構造的にかなり違いがあると考えられる。この様な、ポリマー の比率が多い領域での、セメントの水和過程に関寸る研究 $\left.{ }^{11}\right)$ はある ものの、ポリマーセメント防水層形成過程と、構造についての研究 は、筆者等の知る範囲ではほとんどない。

3. ポリマーセメント系塗膜防水層の作製

3. 1 材料と調合

(1) セメント

セメントは、密度 $3.16 \mathrm{~g} / \mathrm{cm}^{3}$ 、粒子径 $150 \mu \mathrm{m}$ 以下、凝結始発時間

\footnotetext{
* 東京工業大学環境理工学創造専攻 大学院生

** 東京工業大学環境理工学創造専攻 大学院生

*** 東京工業大学建築物理研究センター 教授.工博

Graduate Student, Tokyo Institute of Technology, M. Eng.

Graduate Student, Tokyo Institute of Technology

Prof., Structural Engineering Research Center, Tokyo Institute of Technology, Dr. Eng.
} 
140 分、凝結終結時間 210 分である、市販の普通ポルトランドセメ ントを使用した。

(2) ポリマー

ポリマーは、エチレン酶酸ビニル共重合体(粉体)を使用した。ポ リマーの密度は硬化時でおよそ $1.0 \mathrm{~g} / \mathrm{cm}^{3}$ である。

(3) 調合

試験体はポリマーセメント比(質量比;以下 P/C と記す) 25、100、 150\%の 3 種類とした。なお、水セメント比(W/C) も防水層の物性に 大きな影響を与えるが、水粉体比（セメントとポリマーに対する水 分の質量比）が 40\%以下となると施工が困難となる為、ここではポ リマー混入量に合わせてW/C を 50、80、120\%とした。

3.2 ポリマーセメント防水層の作製

上記調合にて、ポリマーと水を混練したポリマーエマルションを 作製後、セメントを混ぜ、離型剤を塗布したガラス板に塗布した。 なお、塗布量は、一般の防水工事での防水層厚さを参考に、硬化物 の厚さで約 $1 \mathrm{~mm}$ となるようにした。養生は、温度 $20^{\circ} \mathrm{C}$ 、湿度 $60 \%$ R.H. の恒温室にて 4 週間行った。

3.3 ポリマーセメント防水層の力学的性質

今回試験に用いた防水層の力学的性質については、JIS K 6251 に準拠し、ダンベル状一号型を使用して引張試験を行った。その力 学的性質を図 1 に示寸。

\section{4. ポリマーセメント防水層の組織の観察}

\section{1 観察方法}

ポリマーセメント防水層の組織を、EPMA（Electron Probe Micro Analyzer）を用いた面分析により検討した。EPMA 観察試験体は、ポ リマーセメント防水層を約 $3 \mathrm{~mm} \times 3 \mathrm{~mm}$ で切り出したものを、円筒形枠 （直径 $20 \mathrm{~mm} \phi$ ，高さ $15 \mathrm{~mm}$ ）に入れ、エポキシ樹脂を充填した。な お、ポリマーセメントには、比重の異なる材料を混合している事か ら、養生中に厚さ方向で、その分布が変化する可能性がある。その 為、材質的に平均的であると思われる、厚さ方向に対して中央部分 が観察面となるよう試験体を研磨した。また、測定に先立ち観察面 を白金蒸着した。以上の手順で作製した、観察用試験体を写真 1 に 示寸。なお、試験には、日本電 子株式会社製 EPMA (JXA-8200) を用い、加速電圧は $15.0 \mathrm{kV}$ と し、ビームサイズ(分解能)は 1 $\mu \mathrm{m}$ で測定した。

次に、EPMA による、ポリマ 一セメント中のセメント部分 と、ポリマー部分を識別する方

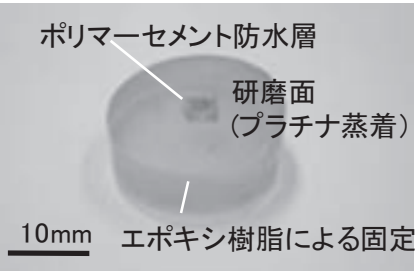

写真1 観察用試験体 法を検討する。面分析を行う対

象元素として、セメント硬化体部分は、ケイ酸カルシウム水和物、 水酸化カルシウム等、カルシウムを主成分とする化合物であること からカルシウム $(\mathrm{Ca})$ 元素とした ${ }^{11,12,13,14)}$ 。一方、ポリマーは炭素を 骨格とする有機物質であることから、炭素 (C) を観察対象元素と した。観察画像は Ca、C それぞれ、元素濃度が高くなるほど黒色 となり、低くなるほど白色となるように、10 段階のグレースケール に変換して表示した。

また参考として、この時同位置の、走査型電子顕微鏡画像
表1 ポリマーセメントの調合表

\begin{tabular}{ccccc}
\hline \multicolumn{2}{c}{$\mathrm{P} / \mathrm{C}$} & 25 & 100 & 150 \\
\hline & \multirow{2}{*}{ ポリマー } & $\begin{array}{l}235.0 \\
(0.235)\end{array}$ & $\begin{array}{l}473.0 \\
(0.473)\end{array}$ & $\begin{array}{l}497.0 \\
(0.497)\end{array}$ \\
& & & & \\
重量比 & セメント & 935.0 & 471.0 & 332.0 \\
$\mathrm{~kg} / \mathrm{m}^{3}$ & & $(0.296)$ & $(0.149)$ & $(0.105)$ \\
& & 469.0 & 378.0 & 398.0 \\
& 水 & $(0.469)$ & $(0.378)$ & $(0.398)$ \\
\hline
\end{tabular}

（ ）内は容積比 $\ell / \mathrm{m}^{3}$

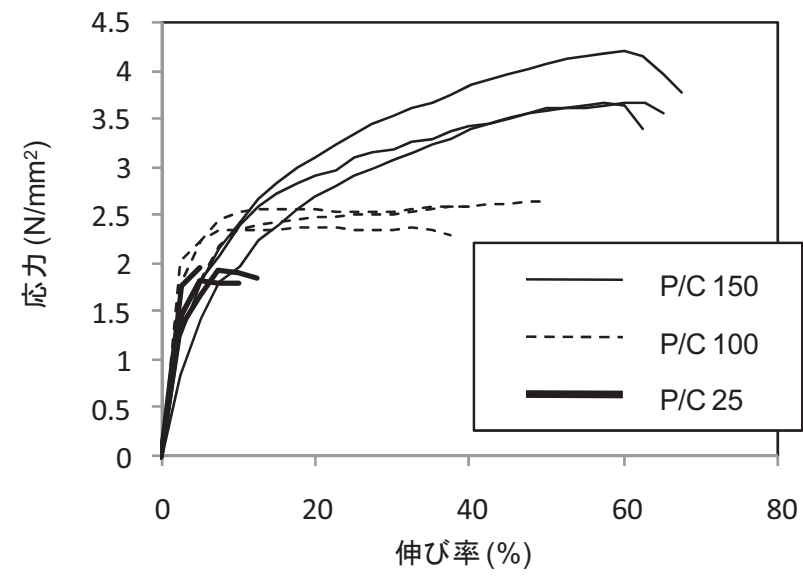

図1 ポリマーセメント防水層の力学的性質

(Scanning Electron Microscope : 以下 SEM 画像)の撮影も行った。

\section{2 観察結果および考察}

図 2 に観察結果を示す。Ca の測定結果では、黒色に近い程 Ca の 濃度が高い事からセメント成分（セメント水和物、未水和セメント 粒子）が多い事を示し、白色に近い程 Ca の濃度が低いことから、 ポリマーか、Ca 以外の成分、もしくは何も存在しない空隙が多い事 を示している。一方、Cの解析結果では、黒色に近い程、ポリマー 成分が多い事を示寸。従って、Ca と C の図はそれぞれ、セメントが 存在する部分にはポリマーは無く、ポリマーが存在する部分にはセ メントは無い事になるので、ほぼ逆の様相を示す事になる。なお、 今回の測定機器の分解能は $1 \mu \mathrm{m}$ である為、この $1 \mu \mathrm{m}$ の格子内には、 セメント、ポリマーの混合している部分があり、両分析結果中では、 この領域は灰色で示されている。この領域においても、Ca と C の混 合比が異なるため濃度差が生じており、さらに、水和率や、水和物 の構成物質の分布も複雑であると考えられる。物性を議論する上で は、これらの詳細な検討が必要と考えられるが、本研究では、ポリ マーセメント塗膜の構成を見る事を主な目的ととらえ、ここを混在 部として表わ寸事にした。すなわち、セメント硬化体部分（黒色）、 ポリマー部分（白色）、両者の混在している部分（死色）の 3 值化 処理を行った。図 3 に 3 值化処理画像を示す。

この分布結果を $\mathrm{P} / \mathrm{C}=100 \%$ を基淮に比較すると、 $\mathrm{P} / \mathrm{C}=25 \%$ ではセメ ント硬化体部分が多く観察された。また、逆に、 $\mathrm{P} / \mathrm{C}=150 \%$ では、セ メント硬化体部分は少なく、ポリマーの中にセメント硬化体部分が 分散している形となる。

5. 数值シミュレーションによる解析 


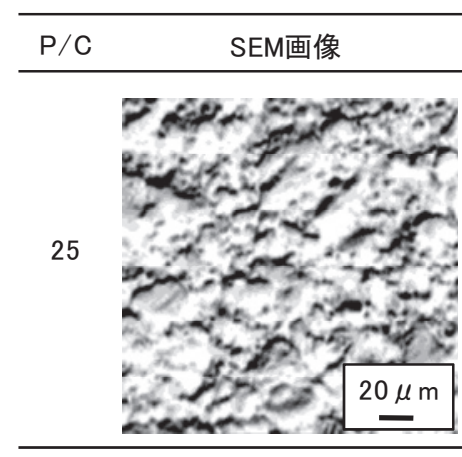

$\mathrm{Ca}$ の分析結果
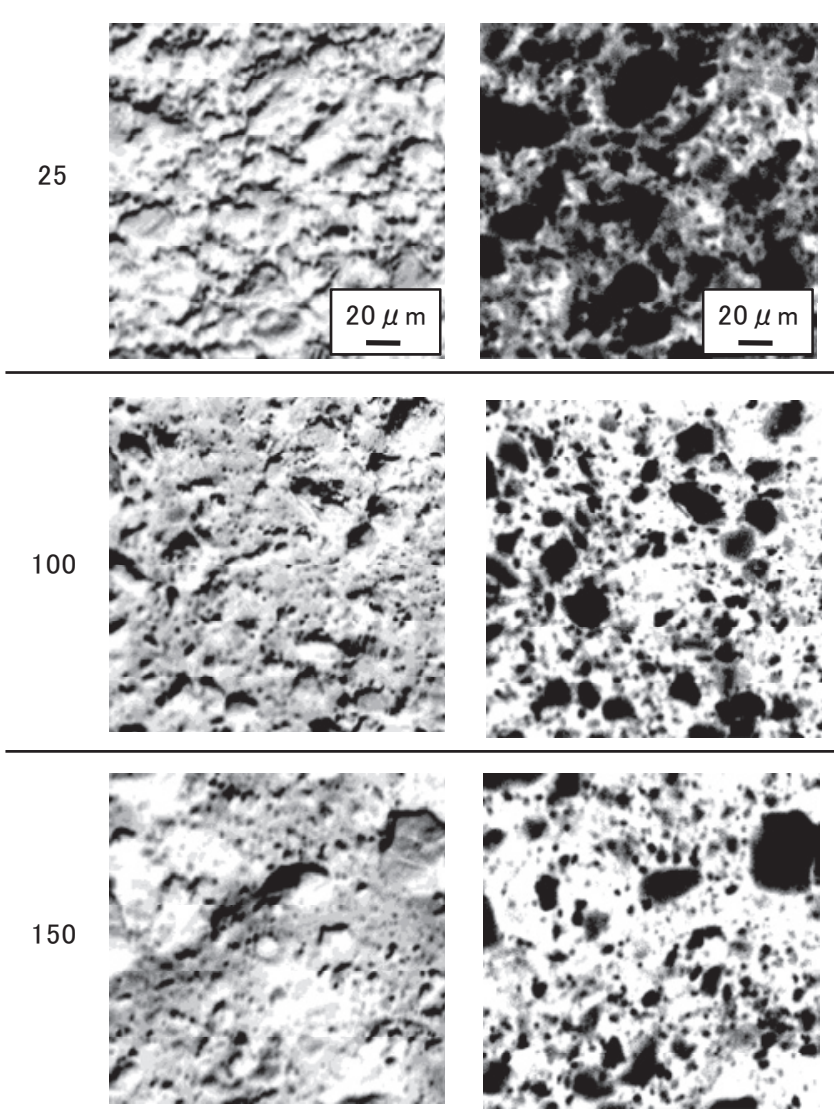
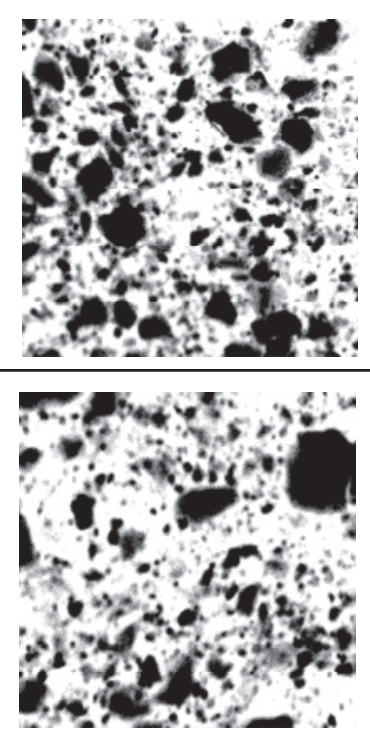

Ca濃度

大

2 表面観察結果とEPMA面分析結果
$\mathrm{P} / \mathrm{C}$ 3值化処理画像
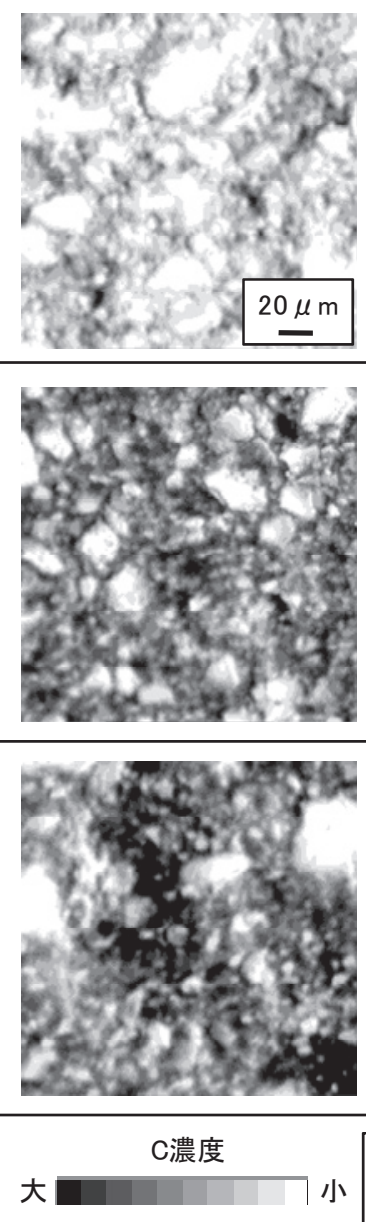

大

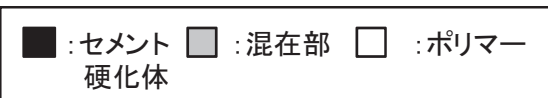

図3 EPMA結果の3值化処理画像
5.1 ポリマーセメント防水層形成のモデル化の概要

通常のポリマーセメント防水層は、塗膜厚さは $1.0 \sim 2.0 \mathrm{~mm}$ とそ れ程厚いものではない。その為、表面からの水分の乾燥速度や、そ れに起因するポリマーの造膜時の粘度変化などの要因が最終的に 造膜したポリマーセメントの微細構造に大きな影響を与えると考 えられる。しかし、EPMA による硬化後の観察ではこの点に関する検 討は難しい。そのため、セメントの水和過程とポリマーの造膜過程 のそれぞれのモデルを作成し、これを組み合わせる事でポリマーセ メント防水層形成過程のモデルを作成し、微細構造の形成について、 数值シミュレーションにより検討を行った。

ポリマーセメント防水層の形成過程において、重要となるのは、 調合時のセメント、ポリマー、水分量の三者の割合である。中でも 水分量は、セメントの水和とポリマーの造膜の双方に重要な役割を 持つ。すなわち、セメントはポリマーエマルションより水分を得る ことにより水和物を形成する一方、ポリマーは、セメントの水和に よる水分の消費と、表面からの乾燥により水分を失い、濃縮され、 最終的にポリマー同士が融着し造膜する。数值シミュレーションで は、この過程を、水和によるセメント硬化体の成長と、ポリマーの 融着とを組み合わせて、ポリマーセメント防水層形成過程を記述し た。

5.2 セメントの水和過程のモデル化
セメントは、セメント粒子中の多種の鉱物と水とが反応すること により、水和物が生成され、これが互いに成長、一体化し、セメン 卜粒子間の空隙を充填してゆく。このセメントの水和反応について、 国内外でいくつもの研究がなされており、各種水和率の予測モデル や、水和生成物の形成の予測モデルが提案されている ${ }^{15,16,17,18,19)}$ 。 例えば、Bentz 等 ${ }^{20}$ は 3 次元セル・オートマトン法を用いて、格子 状に区切られた空間内にセメント成分を配置し、これが溶解・拡 散・水和物を生成するとしたモデル化を行い、セメントの水和反応 時の組織の構成過程を説明している。また、杉山等 ${ }^{21}$ は非定常拡散 過程にあるセメント成分と水が反応して水和物を生成し、セメント 組織を形成していく過程を定量的に表すことの出来るモデルを提 案している。

本研究では、これら既往の研究 20、21) と、先の EPMA 観察結果を基 に、セメントの主成分である $\mathrm{Ca}$ 成分に着目し、水和反応時のセメ ント粒子からの Ca 成分の拡散と、その時の Ca の濃度分布を、拡散 理論を用いて表すこととした。Ca の拡散は式(1)により計算した。 この計算の中では、セメントは球形とし、ここから放射状に Ca 粒 子が拡散すると仮定している。さらに、Ca の拡散速度は、水和物に よる組織の形成に伴い、拡散に対する抵抗性が徐々に増加すると考 えられる。そこで、水和物の生成割合を水和率と考え、初期の拡散 係数 D に対して、拡散係数の変化を水和率に依存する関数とし、式 
（2）にて表現した。なお、水和率は、セメント粒子中の初期の Ca 量に対する、拡散し減少した Ca の割合から式(3)にて求める事とし た。よって、水和終了時は、反応したセメント体積に対して、生成 されるセメントゲルの体積は 2.1 倍程度 ${ }^{14)}$ と言われている事から、 これをもとに計算すると、セメント粒子中で生じる水和は初期の Ca 量の $47 \%$ となり、残り $53 \%$ が外部に拡散する Ca 量となる。

$\partial \mathrm{Ca} / \partial \mathrm{t}=\mathrm{D}_{\tau}\left(\partial{ }^{2} \mathrm{Ca} / \partial \mathrm{x}^{2}+\partial{ }^{2} \mathrm{Ca} / \partial \mathrm{Cy}^{2}\right)$

$\mathrm{D}_{\tau}=\mathrm{D}(1-\alpha)$

$\alpha=\left(\mathrm{Ca}_{\mathrm{t}} / 0.47 \mathrm{Ca}_{0}\right)$

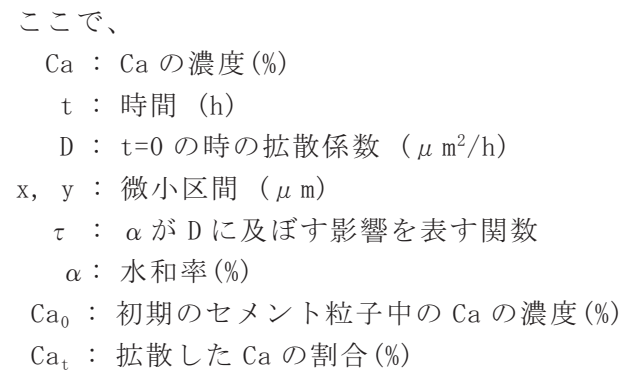

\section{3 ポリマーの造膜過程のモデル化}

図 4 にポリマーのみの造膜概念図を示す。ポリマーエマルション は、蒸発による水分の減少により、徐々に粘度を増しながら、最終 的にポリマー同士が融着し造膜する。この為、蒸発による水分量の 減少により生じる粘度の変化が、ポリマーの硬化速度を示すことに なり、ポリマーの造膜過程を粘度変化として捉えることができると 考えた。なおここでは、水分量の減少を、水ポリマー比(以下 $\mathrm{W} / \mathrm{P}$ と記す)の減少として表現している。また、ここでは水分の蒸発に よる、ポリマーエマルションの厚さの減少量も考慮している。

(1) ポリマーエマルションの水分蒸発量の測定

試験体として、ポリマーエマルションを、W/P=200\%にて調合し、 $50 \times 20 \mathrm{~mm}$ のガラス製板に $2.0 \mathrm{~mm}$ の厚さになるように塗布した。これ を温度 $20^{\circ} \mathrm{C}$ 、湿度 $60 \%$ R. H. の環境下に静置し、重量変化を測定する 事により、水分の蒸発量を求めた。図 5 に測定結果を示す。水分の 蒸発は、初期に急激に進み徐々に緩慢となり、およそ 24 時間でほ ぼ一定值を示す。すなわち、ポリマーはこの時点でほぼ硬化したと 考えられる。この結果をもとに、蒸発速度を、初期の水分量との比 として表わし、図 6 に示寸、式(4)の近似式を求めた。またこれを 用いて、式(5)の様に、W/P の計算を行った。

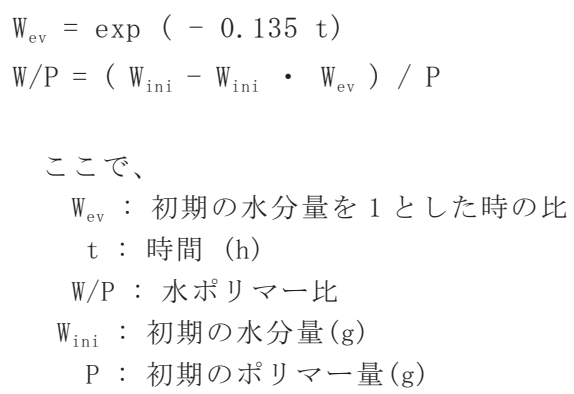

（2）水分の蒸発と粘度の変化の測定

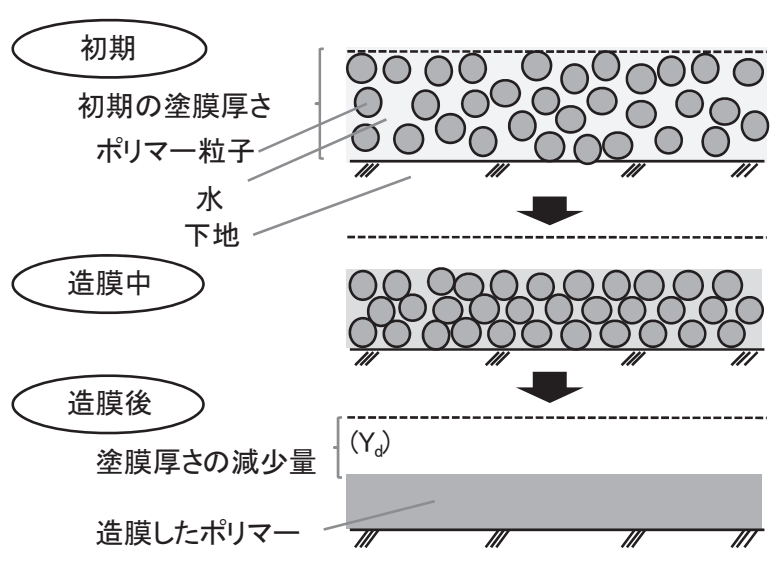

図4 ポリマーの造膜の概念図

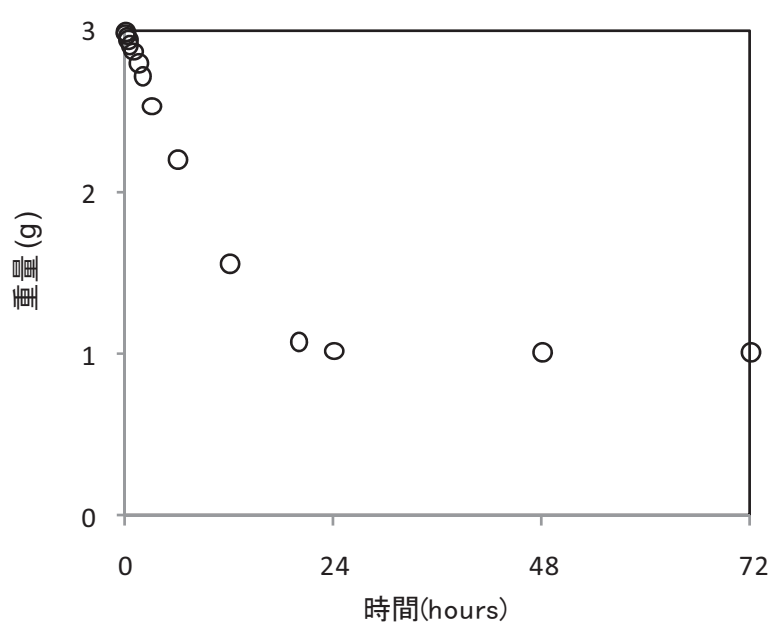

図5 ポリマーエマルション中からの水分の蒸発量の測定結果

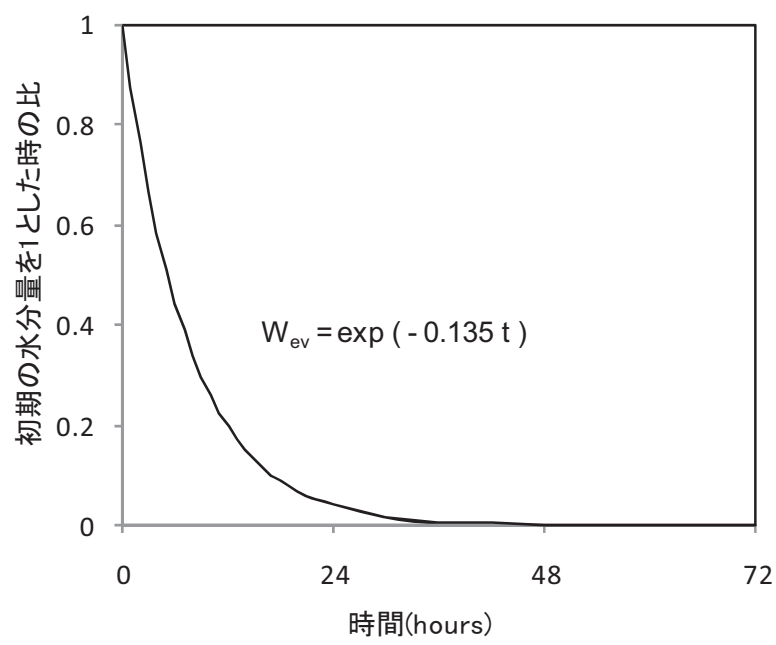

図6 ポリマーエマルション中からの水分の蒸発速度

ポリマーの硬化中の粘度の変化は、剛体振り子型物性試験機 RPT-3000W (エーアンド・デ塂製)を用いて、W/P と粘度の関係を求めた。 試験は W/P=200\%のポリマーエマルションを用いて行った。試験結果 を図 7 に示す。

これより、W/P が 100\%以上の範囲では、粘度の変化はほとんどな く、ここから、水分が蒸発し、W/P が 100\% 50\%の範囲ではゆるや かに粘度が増加し、W/P が $50 \%$ 以下となった辺りから急激に粘度が 増加する。最終的に、W/P=10\%でポリマーはほぼ硬化した。これら 
一連の、ポリマーの粘度の変化を、ほぼ硬化したと考えられる $\mathrm{W} / \mathrm{P}=10 \%$ の時の粘度を 1 、初期值を 0 とした比で表し、図 8 に示す、 式(7)の近似式を求めた。

$\mu_{\mathrm{p}}=2.63 \exp (-0.075 \mathrm{~W} / \mathrm{P})$

$$
\begin{aligned}
& \text { ここで、 } \\
& \mu_{\mathrm{p}}: \text { ポリマーの粘度の比 } \\
& \mathrm{W} / \mathrm{P}: \text { 水ポリマー比 }
\end{aligned}
$$

（3）水分の蒸発による塗膜厚さの減少

ポリマーエマルションからの水分の蒸発により塗膜厚さは減少 するが、それは水分の減少量 $W_{\mathrm{ev}}$ より求めることとし、式(7)で表し た。

$\mathrm{Y}_{\mathrm{d}}=\mathrm{Y} \cdot \mathrm{W} / \mathrm{P} \cdot \mathrm{W}_{\mathrm{ev}}$

$$
\text { ここで、 }
$$

$\mathrm{Y}_{\mathrm{d}}$ : 塗膜厚さの減少量 $(\mu \mathrm{m})$

$\mathrm{Y}$ ：初期の塗膜厚さ $(\mu \mathrm{m})$

\section{4 ポリマーセメント防水層形成過程のモデル化}

ポリマーセメント防水層形成の過程では、セメントの水和とポリ マーの造膜が同時に進行している。この 2 つの現象を制御している のは水分量の変化であり、水分量の変化を考慮する事でセメントの 水和とポリマーの造膜を同時に表す事ができ、ポリマーセメント防 水層形成過程の再現が可能であると考えられる。

すなわち、セメントの水和による Ca の拡散速度は、水分の減少 によりポリマーの粘度が増加する事により低下寸る。一方、セメン 卜の水和による水分の消費 ${ }^{16,22,23)}$ が、ポリマーの硬化速度を速める と考えられる。水和による水分の減少についてであるが、セメント の水和が終了寸るまでに必要な水量については諸説あるが、一般的 にはセメント量の約 $40 \%{ }^{24,25)}$ と言われている。そこで、水和による 水分の減少量を初期のセメント量と、セメントの水和率より式(8) で表すこととした。

$$
\mathrm{W}_{\alpha}=0.4 \alpha \mathrm{C}
$$

$$
\text { ここで、 }
$$

$\mathrm{W}_{\alpha}:$ 水和による水分の減少量 $(\mathrm{g})$

C ：初期のセメント重量 $(\mathrm{g})$

また、ポリマーセメント中でのセメントの水和と蒸発による水分 の減少によるW/P の変化は、式(4)と、（5）、（8）より、最終的に、 式(9)で表される。

$\mathrm{W} / \mathrm{P}_{\mathrm{c}}=\left(\left(\mathrm{W}_{\mathrm{ini}}-\mathrm{W}_{\mathrm{ini}} \cdot \mathrm{W}_{\mathrm{ev}}\right)-\mathrm{W}_{\alpha}\right) / \mathrm{P}$

ここで、W/ $\mathrm{P}_{\mathrm{C}}$ ：ポリマーセメント中の水ポリマー比

次に、ポリマーの粘度がセメントの水和速度に及ぼす影響を表す

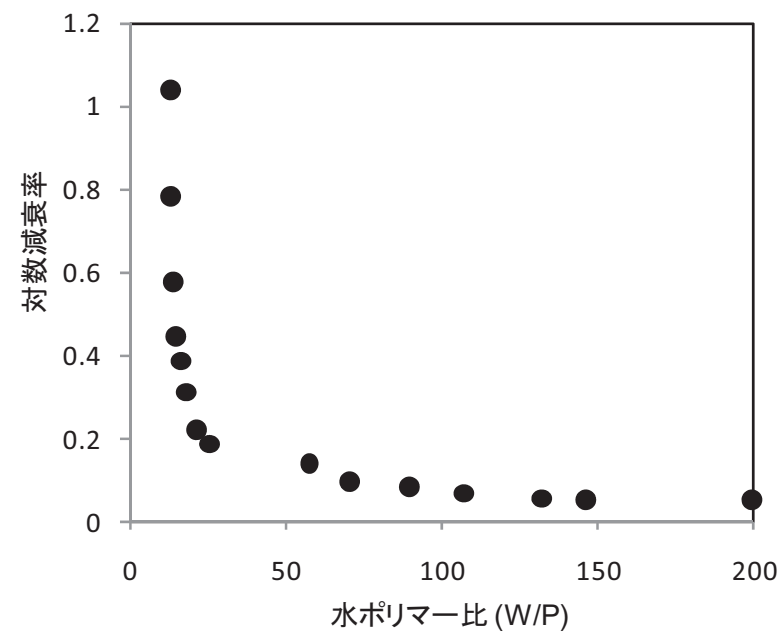

図7剛体振り子型物性試験機による測定結果

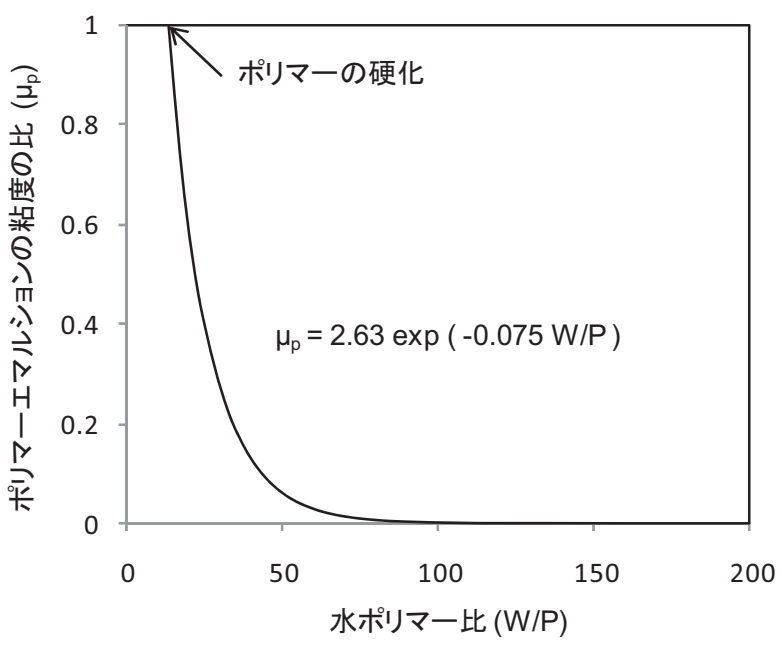

図8 ポリマーエマルションの粘性とW/Pの関係

関数は、式 (6)、（9)から、式(10)により求めた。

$\mu_{\mathrm{PC}}=2.315 \exp \left(-0.13 \mathrm{~W} / \mathrm{P}_{\mathrm{c}}\right)$

ここで、 $\mu_{\mathrm{PC}}$ ：ポリマーセメント中のポリマーの粘度の比

よって、ポリマーセメント中の Ca 粒子の拡散は、ポリマーの粘 度の変化を $\mathrm{Ca}$ の拡散速度の影響因子とし、式(11)で表される。

$\partial \mathrm{Ca} / \partial \mathrm{t}=\left(1-\mu_{\mathrm{PC}}\right) \mathrm{D}_{\tau}\left(\partial^{2} \mathrm{Ca} / \partial \mathrm{x}^{2}+\partial^{2} \mathrm{Ca} / \partial \mathrm{Cy}^{2}\right)$

また、水分の蒸発による防水層厚さの減少は、図 9 に示すように、 それぞれのセメント粒子の垂直方向の相対的位置関係を保ちつつ、 全体的に近接し、厚さを減少させると考えることとした。すなわち、 ある位置に存在するセメント粒子の移動量を式(12)で表し、減少し た体積中に、この分だけ厚さ方向に移動させ、再配置する事で表し た。

$Y_{n}=Y_{D}\left(H-Y_{n}\right) / H$ 
ここで、 $\mathrm{WP}_{\mathrm{C}}$ ：ポリマーセメント中の水ポリマー比

$\mathrm{Y}_{\mathrm{d}}$ ：任意の位置でのセメントの沈降量 $(\mu \mathrm{m})$

$\mathrm{H}$ ：全体の高さ $(\mu \mathrm{m})$

$\mathrm{Y}_{\mathrm{n}}$ : 上面からの距離 $(\mu \mathrm{m})$

5.5 ポリマーセメント防水層形成シミュレーションプログラム

前述したセメントの水和モデルと、ポリマーの造膜モデルとを組 み合わせ、ポリマーセメントの造膜過程のシミュレーションを行っ た。シミュレーションのフローチャートを図 10 に示す。

まず、セメントの水和により Ca がエマルション中に拡散する。 また、この水和による水の消費と、蒸発により水分量が減少し、エ マルションは濃縮され、ポリマーの粘度が大きくなり、造膜過程が 進行する。今回のシミュレーションは EPMA による観察試験と合わ せて、養生条件は $20^{\circ} \mathrm{C} 、 60 \%$ R. H. 、材齢 28 日後の状況を調べようと している為、ここまでを 1 サイクル（1 時間）として、これを 28 日間分繰り返した。なお、W/P が 10\%以下となった場合、ポリマー が造膜したと判断し、セメントの水和の進行は止まる事になる。

シミュレーションの結果の出力は EPMA の結果と合わせて縦横 $200 \times 200 \mu \mathrm{m}$ 角となるように、水分の減少によるポリマーの造膜時 の膜厚さの減少分を考慮し、初期值は縦横 400 x $200 \mu \mathrm{m}$ 角とし、

これを $1 \mu \mathrm{m}$ ずつに格子を区切った。

セメント粒子の直径は 20、10、6 $\mu \mathrm{m}$ とし、セメントの水和の早 期強度をつかさどるとされる C 3 S の粒度分布を参考 ${ }^{26)}$ に、それぞれ 面積比で $1 ： 2 ： 5$ となるように乱数を用いてランダムに配置し た。また、Ca の拡散係数については、初期の調合条件や、養生中の 表面からの水分の蒸発により、刻々と変化するW/C の影響も考えら れるが、本シミュレーションでは、水分が存在する場合は一定の速 度で水和が進行すると仮定した。そこで、Ca の拡散係数は、W/C=60\% のセメントペーストの水和率 ${ }^{17)}$ の速度が、普通ポルトランドセメン 卜の水和速度に合う值として、1. $2 \times 10^{-16} \mathrm{~m}^{2} / \mathrm{s}$ を用いる事とした。参 考として水和率と経過時間の関係を図 11 に示す。

\section{6 シミュレーション結果}

シミュレーションの結果を図 12 に示寸。シミュレーション結果 は、ポリマーエマルション中にセメント粒子が分散、成長するよう な様相であり、EPMA の観察結果同様、 $1 \mu \mathrm{m}$ の格子の中には、セメ ント成分部分、ポリマー成分部分、この両者が混在している部分が 生じる。すなわち、セメント成分の周りにセメントとポリマーの混 在部分が存在し、さらにその外側がポリマー成分のみとなる 3 相構 造となる。その為、セメントと混在領域の境界と、ポリマーと混在 領域の境界を定める必要があり、それを図 13 に示すような概念に より決定した。すなわち、混練直後のセメント粒子と水との界面を 境界とした。それより外側にセメント水和物は成長するが、そこに はポリマーが存在するため、その部分は、セメント硬化体とポリマ 一が混在していると考えられる、これを混在部分とした。次に、ポ リマーと混在領域の境界は、Ca の濃度が 0\%以下である領域を、セ メント硬化体は存在せずポリマーのみであるとした。

また、ポリマーセメント防水層の形成は、今回の試験環境下では およそ半日でポリマーの造膜が完了し、水分の乾燥と同時にセメン 卜の水和による組織形成も終了していると予想される。このように、 ポリマーセメント防水層は 1～2mm 程度の膜厚さで施工され、表面

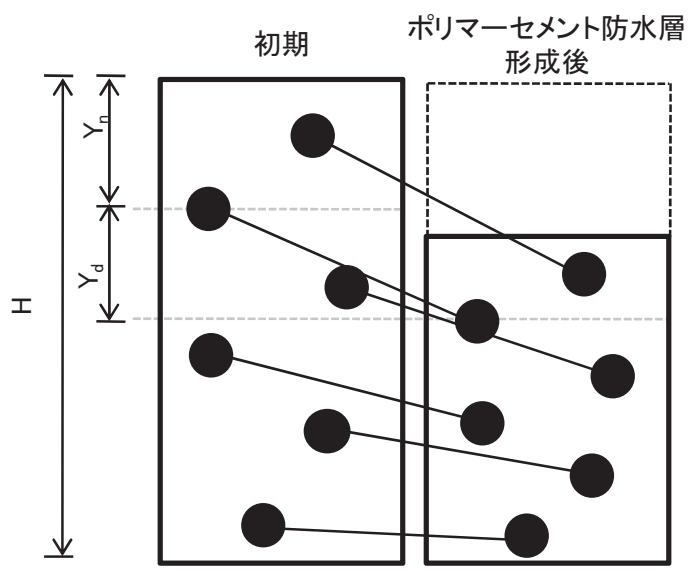

図9 体積変化とセメント粒子の位置の移動の概念図

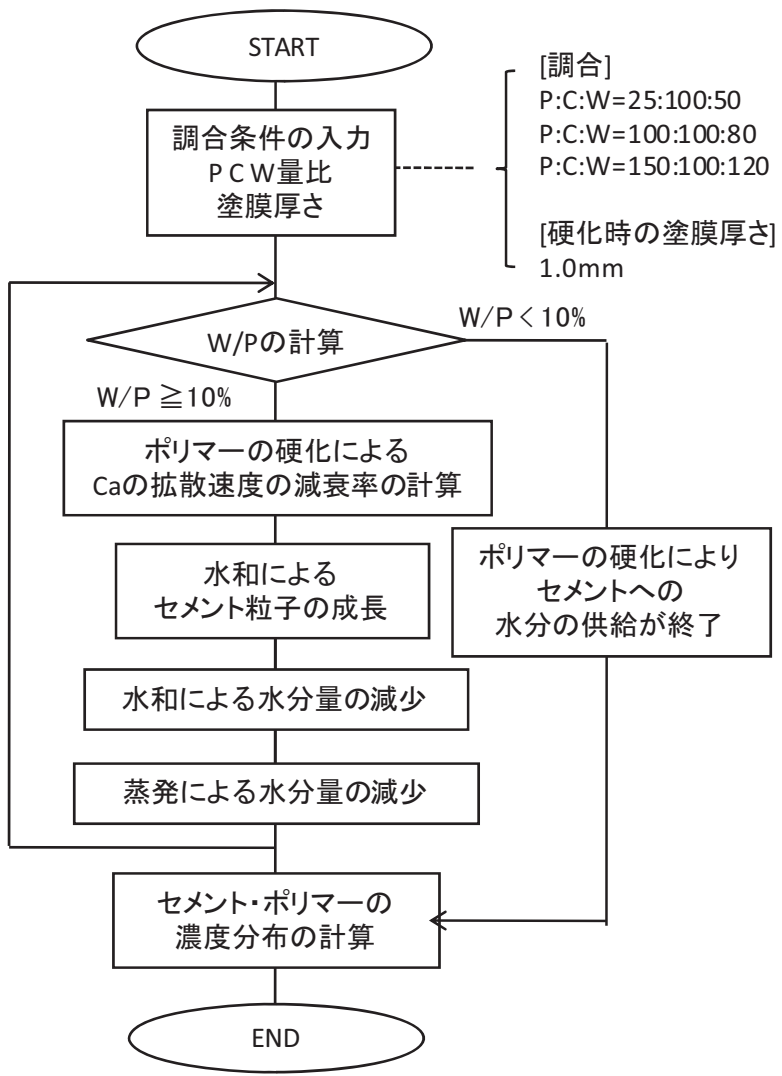

図10 ポリマーセメント防水層形成過程の数值解析フローチャート

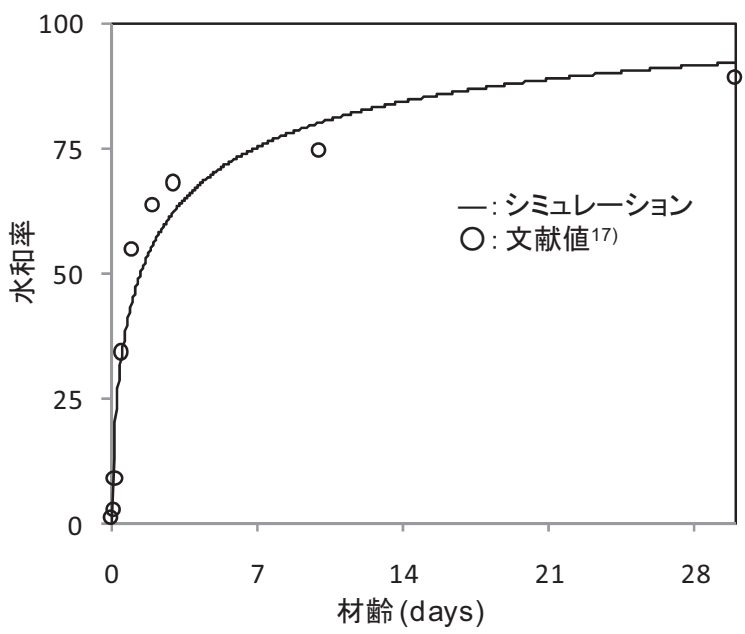

図11 W/C=60\%のセメントペーストの水和率の計算結果 

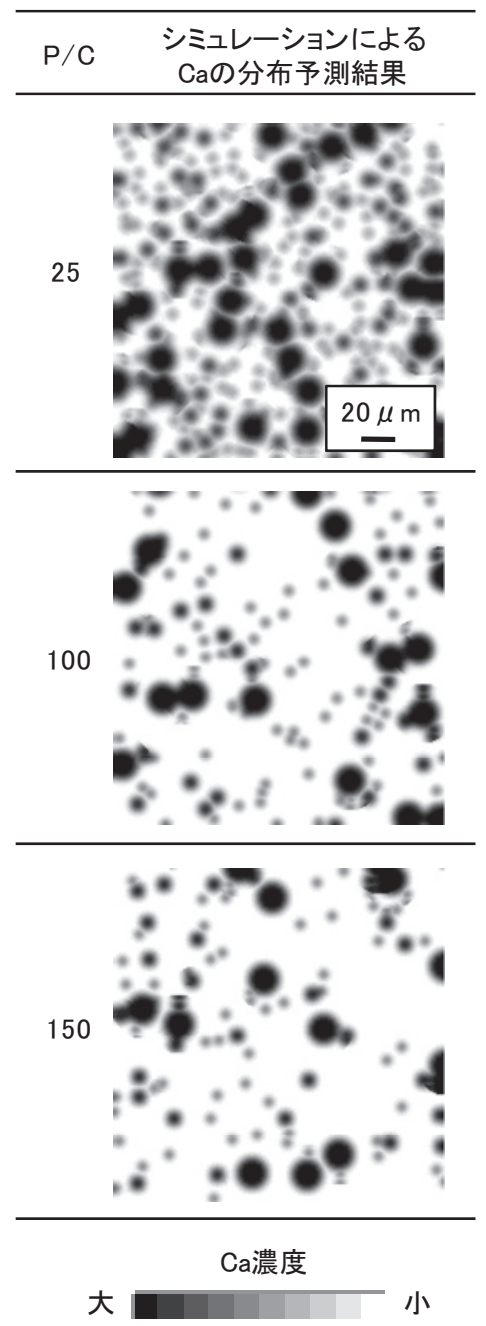

図12 シミュレーションによる予測結果

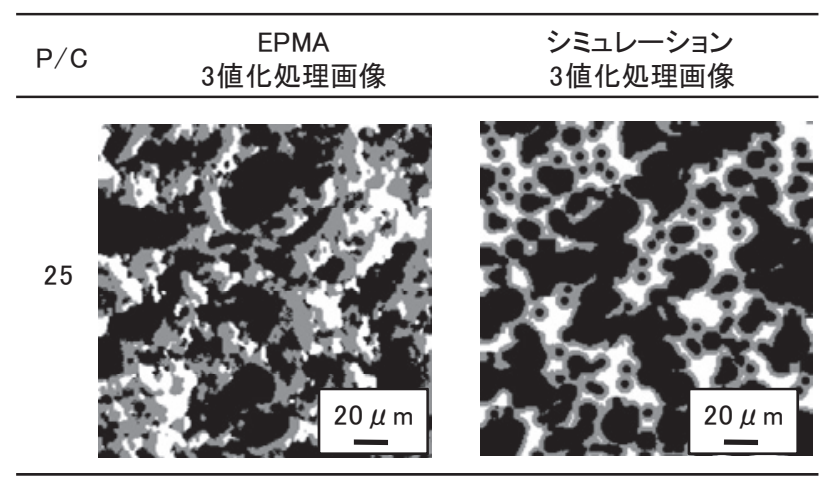

\begin{tabular}{ccc}
\hline $\mathrm{P} / \mathrm{C}$ & $\begin{array}{c}\text { EPMA } \\
\text { 結果 }\end{array}$ & $\begin{array}{c}\text { シミュレーション } \\
\text { 結果 }\end{array}$ \\
\hline
\end{tabular}
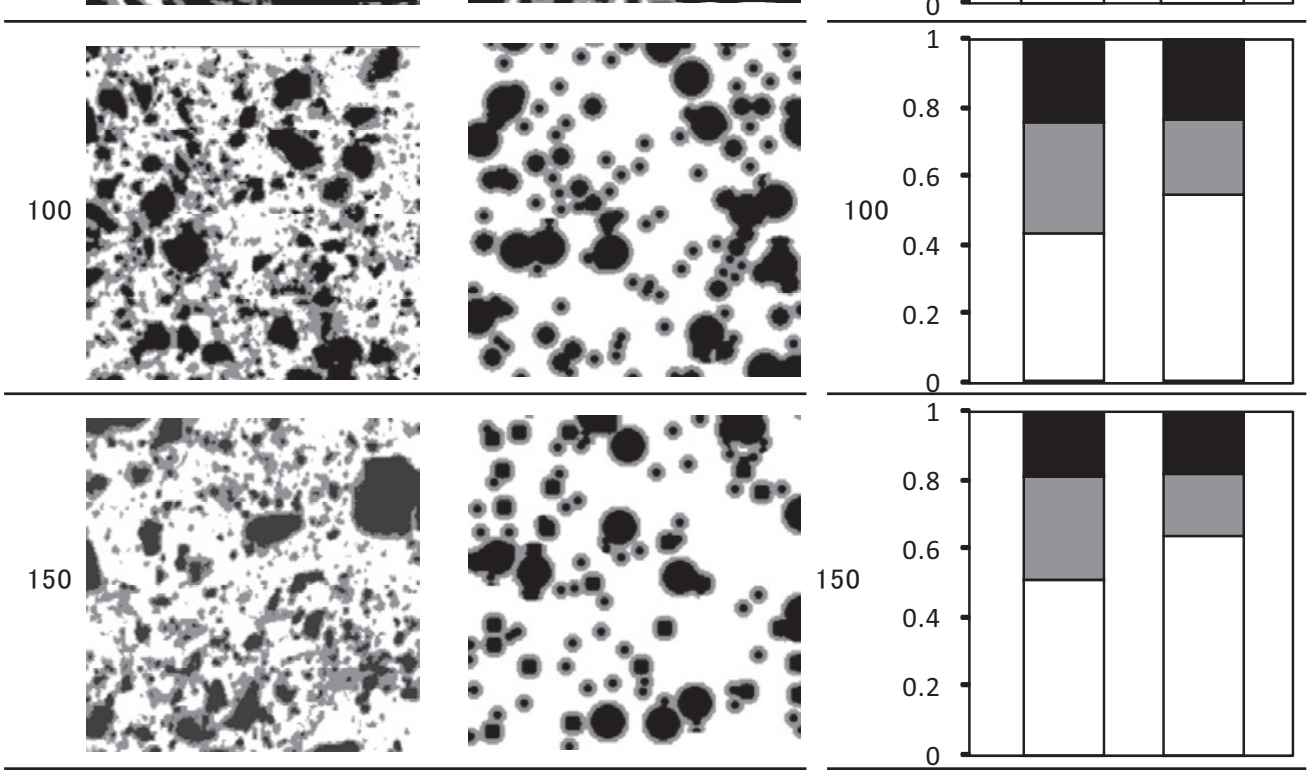

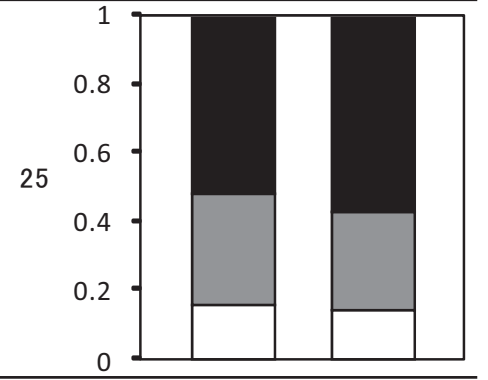

:セメント $\square$ :混在部 $\square$ :ポリマー 硬化体

図15 EPMA結果の3值化処理画像
:セメント $\square$ :混在部 $\square$ :ポリマー

図14 EPMA結果の3值化処理画像
混練直後

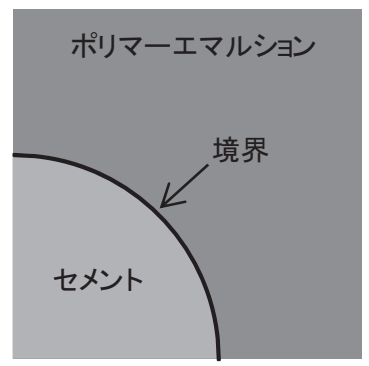

ポリマーセメント防水層形成後
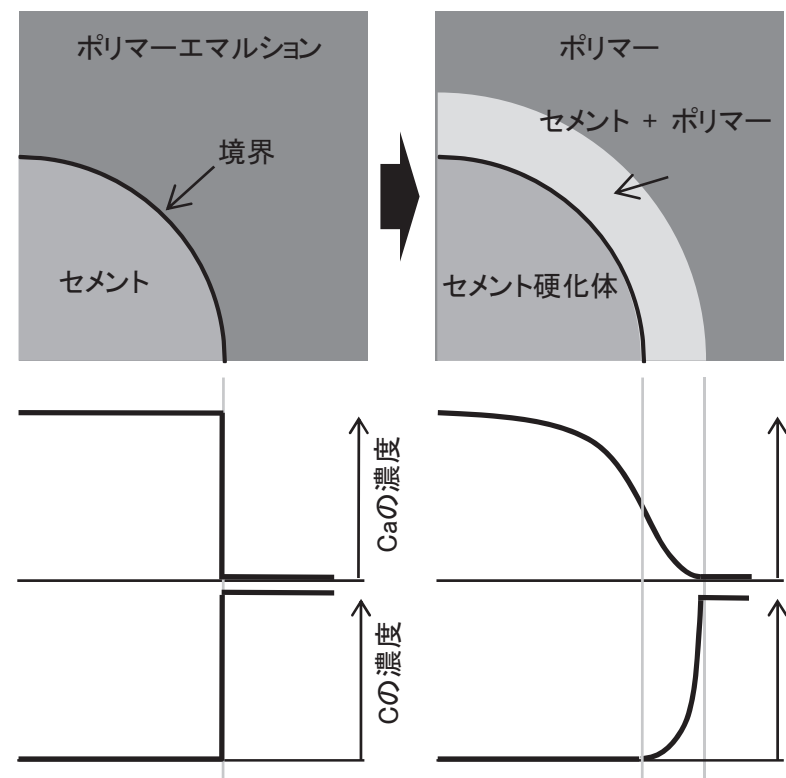

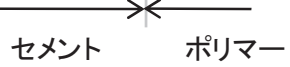

のみ

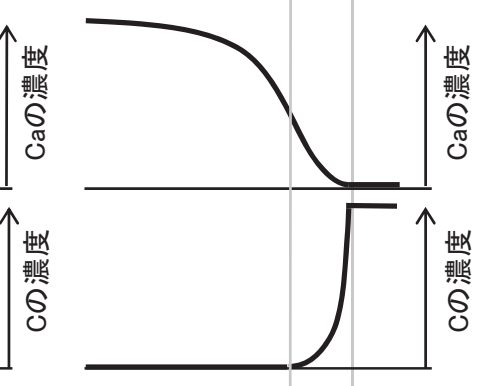

セメント 混在部ポリマー

硬化体のみ

からの水分の蒸発速度の影響が大きい。その為、同一の調合で作製 されても施工時期や施工部位などの違いによる養生条件の違いに より、出来あがる防水層の構造や物性が異なる可能性が懸念される。

5. 7 EPMA 結果とシミュレーション結果との比較

以上の境界の定め方により、EPMA の結果同様 3 值化した。図 14 に EPMA の 3 值化画像との比較を、図 15 に、セメント硬化体部分、 ポリマー部分、両者が混在する部分の面積占有率をそれぞれ示す。 EPMA による結果と比較すると、ほぼセメントとポリマーの存在割合 を再現していると言える。

6. 結論

本研究の結果は以下の通りである。

（1）ポリマーセメントの EPMA 観察により、P/C の少ない場合は、セ メント硬化体を中心とするリジッドな構造となっているが、P/Cが 多い場合にはポリマーの中にセメント硬化体が分散した構造とな っている事を明らかにした。

（2）ポリマーエマルションの水分は、セメントの水和と表面からの 蒸発により、全体的に減少することを考慮したポリマーセメントの モデル化を行い、防水層形成のシミュレーション手法を開発した。 
(3)シミュレーション結果はEPMA 観察結果を概ね表わしている事を 確認し、シミュレーション手法はポリマーセメント防水層の微細構 造研究に有用であること考えられた。

\section{謝辞}

本研究中における、剛体振り子型物性試験機による測定を行うに あたっては、サンスター技研株式会社、また、EPMA 観察を行う東京 工業大学分析支援センター（大岡山）に多大なご協力をいただきま した。また、胡桃澤清文准教授 (北海道大学)には貴重なご意見をい ただきました。ここに付記し、心より感謝を表します。

\section{参考文献}

1）林正弘；ポリマーセメント系塗膜防水に関寸る調査研究，日本建築学会大 会学術講演梗概集. A-1，材料施工，pp249-250，2002.8

2）菅原享; ポリマーエマルション皮膜の皮膜特性に及ぼすポリマー粒子の融 着の影響, 日本化学会誌 No. 8, pp463-468，2001.8

3）青山幹: エチレンー酶酸ビニル共重合体エマルジョンを主要材料とするポ リマーセメント複合材：第 1 報、急結性ポリマーセメントペーストに関す る検討, 日本建築学会大会学術講演梗概集. 構造系 54, pp. 231-232 1979.9

4) U. Musarrat; A note on the formation of $\mathrm{Ca}(\mathrm{OH})_{2}$ Crystals in polymer-modified mortars, Cement and Concrete Research Vol.23, pp484-485, 1993

5) L. Montanaro; Influence of added polymer emulsions on the short-term physical and mechanical characteristics of plastic mortar, Cement and concrete research Vol.20, pp62-68, 1990

6) A. Beeldens; From microstructure to macrostructure: an integrated model of structure formation in polymer-modified concrete, Materials and Structure Vol. 38, pp601-607, 2005.7

7) R. 011itrault-Fichet; Microstructural Aspects in a Polymer-Modified Cement, Cement and Concrete Research, Vol.28, No. 12, pp1687-1693, 1998. 12

8) S. Etsuo; Composite Mechanism of Polymer Modified Cement, Cement and Concrete Research Vol.25, No. 1, pp127-135, 1995.1

9）五十嵐太; 高性能减水剂を添加したポリマーセメントモルタルの性質，コ ンクリート工学年次論文集，Vol.24，No. 1，2002

10）落合香織; 初期材齢における EVA 混入ポリマーセメントモルタルの組織構 造，日本建築学会大会学術講演梗概集. A-1，pp685-686，1997.9

11）小寺賢； SPring-8 放射光 $X$ 線回折法による EVA エマルション中のアルミ ナセメントの水和過程, 材料 Vol. 54, No. 7 pp. 780-784，2005.7

12）安伸二; EPMA による低水結合材比各種セメントペーストの水和組織の検 討, 日本建築学会大会学術講演梗概集. A-1, 材料施工, pp8333-834, 1995.8

13）白木亮司; EPMA によるセメント硬化体中の微量元素の定量分析方法，コ ンクリート工学年次論文集 Vol. 12，pp365-366，1990

14）胡桃沢清文；セメントペーストの空隙構造の 3 次元測定法の開発，日本 建築学会構造系論文集 第556 号, pp9-14，2002.6

15）五十嵐心一; セメントペーストの反射電子像とシミュレーション組織の 比較，コンクリート工学年次論文集 Vol. 29，pp687-692，2007

16）蔵重勲;セメント硬化体の相組成を考慮した而久性能評価技術の現状と課 題, 電力中央研究所報告 調査報告 No05061, 2005.7

17）丸山一平；ポルトランドセメントの水和反応モデルに関する研究, 日本建 築学会構造系論文集 第593 号, pp1-8，2005.7

18) S. J. PREECE; On the initial stages of cement hydration, Journal of Engineering Mathematics Vol. 40, pp43-58, 2001

19) F. Tzschichholz; Reaction-diffusion model for the hydration and setting of cement, Physical Review E, Vol. 53, pp2629-2637, 1996.3

20) D. P. BENTZ; Computer simulation of the diffusivity of cement-based materials, Journal of Materials Science Vol.27, pp2083-2092, 1992

21）杉山央; 非定常拡散理論に基づくセメントの水和反応・組織形成モデル, セメント・コンクリート論文集, 第 53 号, pp. 50-57，1999. 12

22）五十嵐心一，水和反応の進行にともなうセメントペースト構成相の空間
分布構造の変化，土木学会論文集E Vol. 63, No. 3 pp. 444-458, 2007.3 23）伊与田岳史; 養生環境の違いによるセメント硬化体の水和進行と内部水 分, 生産研究 研究報告 52 巻 10 号, pp47-50, 2000. 10

24）永松静也; 乾燥を受けるセメント硬化体の水和の進行を表寸式，日本建築 学会構造系論文集 361 号, pp21-30, 1986.3

25）長㴰重義；コンクリート便覧[第二版]，p38，1976.2

26) R. Berliner : Quasielastic neutron scattering study of the effect of water-to-cement ratio on the hydration kinetic of tricalcium silicate, Cement and Concrete Research Vol. 28, No. 2, pp231-243， 1998

（2009年 5 月 8 日原稿受理，2009年 9 月 25 日採用決定） 